\title{
Amylase resistance and insolubility of ageing costal cartilage in man
}

\author{
J. K. VAN DER KORST, A. G. W. LANSINK, AND
}

A. E. M. A. VAN HOOFT-AARNOUTSE

From the Division of Rheuinatology, Department of Internal Medicine, and the Laboratory of Biochemistry, Department of Pathology, University of Nymegen, Netherlands

The solubility of human costal cartilage during exhaustive digestion with proteases (van der Korst, Sokoloff, and Miller, 1968) or $5 \mathrm{M}$ guanidine- $\mathrm{HCl}$ (Miller, van der Korst, and Sokoloff, 1969) decreases with ageing. These observations stimulated us to investigate the quantitative effect of glycosaminoglycan and protein-degrading enzymes on costal cartilage in regard to age. The first enzyme studied was $a$-amylase, because crude preparations of this enzyme seem to have a peculiar effect on the intercellular substance of connective tissues, i.e. solubilization of collagen (Steven, 1964) and release of acid glycosaminoglycans (Quintarelli, Dellovo, Balduini, and Castellani, 1969).

\section{Material and methods}

Costal cartilage was obtained from nine autopsy cases, varying in age from 14 to 93 years. No cases of rheumatic or collagen disease were included. The perichondrium and immediately subjacent tissues were dissected away and areas of calciñcation were removed. The cartilage was cut into small pieces with a scalpel and then lyophilized. The dried samples were ground in an electromagnetic micromill with an oscillating steel ball (Fritsch Pulverisette 0). Only powder passing through a sieve with openings of $0.1 \mathrm{~mm}$. diameter was used for the following experiments.

From each of the nine pulverized cartilage batches two 500 -mg. samples were taken. To both samples $12 \cdot 5 \mathrm{ml}$. 0.02 molar phosphate buffer in 0.8 per cent. $\mathrm{NaCl} \mathrm{pH}$ 6.9 was added, and to one of them $12.5 \mathrm{mg}$. crude $\alpha$-amylase ${\left(\text { Sigma }^{R}\right.}$ type III-A, from Bacillus subtilis, lot 117 B-0040, 6.4 units per mg.). (One unit releases $1 \mathrm{mg}$. maltose from starch in $3 \mathrm{~min}$. at $\mathrm{pH} 6.9$ at $20^{\circ} \mathrm{C}$.). Both samples were simultaneously incubated for 1 hour at $37 \mathrm{C}$. under constant stirring. Preliminary experiments, in which the amount of crude $x$-amylase added varied from 0 to $2500 \mathrm{U}$ per sample and the incubation time varied from 0.5 to 7 hours, had demonstrated that under the conditions ultimately chosen, a maximum release of uronic acid was obtained from a 42-year-old cartilage sample.

To inactivate the enzyme both samples were heated to boiling temperature after 1 hour of incubation. After centrifuging and filtering, the amounts of hexosamine and uronic acid were estimated in the supernatant. Hexosamine content was determined according to the method of Antonopoulos, Gardell, Szirmai, and de Tyssonsk (1964) and uronic acid content according to that of Bitter and Muir (1962). One ml. of the supernatant of some chosen samples was hydrolysed by adding $5 \mathrm{ml}$. $6 \mathrm{~N} \mathrm{HCl}$ and incubated for $24 \mathrm{hrs}$ at $105^{\circ} \mathrm{C}$. in vacuumsealed glass tubes for amino acid analysis. Analyses were performed on a Phoenix M 7800 Automatic Amino Acid Analyzer, employing a single column and gradient elution according to the method of Miller and Piez (1966) with some slight modifications. Because of overlap of amino sugars on the graphic record we were unable to calculate the amount of methionine present.

Similar experiments were performed on three cartilage samples, using purified $a$-amylase $\left(\right.$ Sigma $^{R}$ type II-A, from Bacillus subtilis, lot 108 B-0590, 1000 units per mg.), instead of crude $a$-amylase. These samples were obtained from autopsy cases, respectively 19, 46, and 84 years of age. In these experiments no amino acid analyses were done.

\section{Results}

Incubation of lyophilized costal cartilage powder in phosphate buffer, containing $64 \mathrm{U}$ crude $a$-amylase per $\mathrm{ml}$., resulted in the release of an appreciable amount of uronic acid exceeding the amount released during incubation in phosphate buffer without amylase (Table I, opposite). However, the older the cadaver from which the cartilage was obtained, the smaller was the amount of uronic acid extracted from the cartilage, both by amylase-activity and by phosphate buffer cnly. Roughly ten times as much uronic acid is solubilized in phcsphate buffer from the cartilage of a 14-year-old cadaver as from that of a 93-ycar-old cadaver. By subtracting the amount of urcnic acid roleased in the control experiment (buffer only) from the amount liberated in phosphate buffer containing crude a-amylase, the 'net c.fest' of crude a-amylase was estimated. As s'hown in Table I, the 'net effect' of crude a-amylase on cartilage of a 14-year-old, in regard to uronic acid release, is about twenty times as great as the effect on the cartilage of a 93-year-old.

Similar results were obtained in regard to the liberation of hexosamine (Table I). There is a marked decrease with age of the amount of hexosamine in the supernatant, both after incubation with phosphate buffer plus amylase and after incubation with phosphate buffer only. As with uronic acid, the amount of hexosamine extracted by phosphate buffer from the cartilage powder from a 93-year-old is about one tenth of that extracted from a 14-year- 
Table I Amount of uronic acid and hexosamine (mg./g. dried cartilage) in supernatant after 1 hrs incubation in phosphate buffer and in phosphate buffer plus crude a-amylase $(1600 \mathrm{U} / \mathrm{g}$. cartilage)

\begin{tabular}{|c|c|c|c|c|c|c|}
\hline \multirow{2}{*}{$\begin{array}{l}\text { Age } \\
\text { (yrs) }\end{array}$} & \multicolumn{3}{|c|}{ Uronic acid released } & \multicolumn{3}{|c|}{ Hexosamine released } \\
\hline & $\begin{array}{l}\text { Phosphate } \\
\text { buffer }\end{array}$ & $\begin{array}{l}\text { Phosphate buffer }+ \\
\text { crude a-amylase }\end{array}$ & $\begin{array}{l}\text { 'Net effect' of } \\
\text { crude a-amylase }\end{array}$ & $\begin{array}{l}\text { Phosphate } \\
\text { buffer }\end{array}$ & $\begin{array}{l}\text { Phosphate buffer }+ \\
\text { crude a-amylase }\end{array}$ & $\begin{array}{l}\text { 'Net effect' of } \\
\text { crude a-amylase }\end{array}$ \\
\hline $\begin{array}{l}14 \\
24 \\
37 \\
44 \\
55 \\
66 \\
73 \\
86 \\
93\end{array}$ & $\begin{array}{r}32.8 \\
17.6 \\
8.9 \\
12.3 \\
6.2 \\
3.9 \\
4.7 \\
4.4 \\
3.9\end{array}$ & $\begin{array}{r}56 \cdot 6 \\
34 \cdot 8 \\
17 \cdot 6 \\
19 \cdot 6 \\
10 \cdot 5 \\
7 \cdot 4 \\
6 \cdot 6 \\
5 \cdot 8 \\
5 \cdot 1\end{array}$ & $\begin{array}{r}23 \cdot 8 \\
17 \cdot 2 \\
8 \cdot 7 \\
7 \cdot 3 \\
4 \cdot 3 \\
3 \cdot 5 \\
1 \cdot 9 \\
1 \cdot 4 \\
1 \cdot 2\end{array}$ & $\begin{array}{r}47 \cdot 7 \\
25.6 \\
19 \cdot 2 \\
19.7 \\
9.9 \\
5.9 \\
5 \cdot 2 \\
3.6 \\
4.1\end{array}$ & $\begin{array}{l}96 \cdot 1 \\
68 \cdot 2 \\
48 \cdot 1 \\
51 \cdot 2 \\
30 \cdot 8 \\
22 \cdot 1 \\
17 \cdot 0 \\
11 \cdot 6 \\
12 \cdot 2\end{array}$ & $\begin{array}{r}48 \cdot 4 \\
42 \cdot 6 \\
28 \cdot 9 \\
31 \cdot 5 \\
20 \cdot 9 \\
16 \cdot 2 \\
11 \cdot 8 \\
8 \cdot 0 \\
8 \cdot 1\end{array}$ \\
\hline
\end{tabular}

old. There is a less sharp decrease in the 'net effect' of crude $a$-amylase on the release of hexosamine, that from a 93-year-old being approximately onesixth of that from a 14-year-old.

Comparing the 'net effect' of crude $a$-amylase on hexosamine and uronic acid release (Table I), both decrease markedly with age, the decrease being somewhat more pronounced for hexosamine. A significant increase, concomitant with age, of the hexosamine/uronic acid ratio released from the cartilage by amylase digestion was found, whereas the hexosamine/uronic acid ratio in the buffer extract decreased slightly with age (Fig. 1).

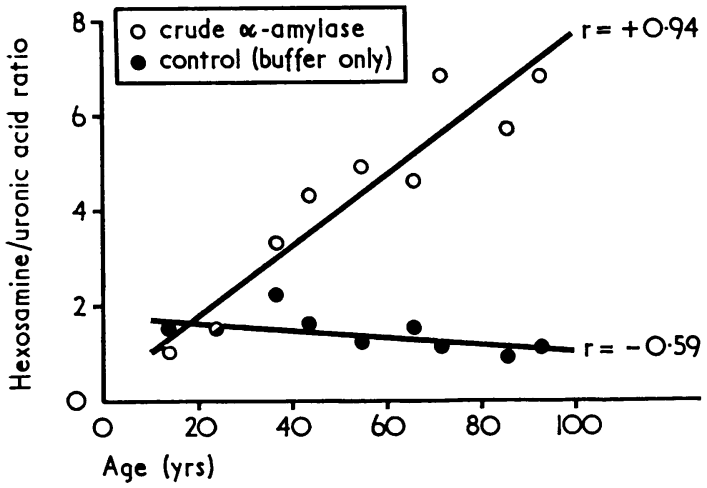

FIG. 1 Hexosamine/uroric acid ratio released from human costal cartilage samples of different ages, by crude a-amylase $(1600 \mathrm{U} / \mathrm{g}$. dried cartilage $)$ ard $0.02 \mathrm{M}$ phosphate huffer, pH 6.9.

The effect of varying amounts of crude $a$-amylase and purified $a$-amylase on the libeiation of uronic acid was studied in dried cartilage powder from a 42-year-old cadaver. Crude $\alpha$-amylase was more than ten times as potent in releasing uronic acid from cartilage as purified $a$-amylase (Fig. 2). Like crude $a$-amylase, purified $a$-amylase was shown to be more effective on young than on old cartilage, in releasing both uronic acid and hexcsamine (Table II, overleaf).

Judging from the results of the amino acid

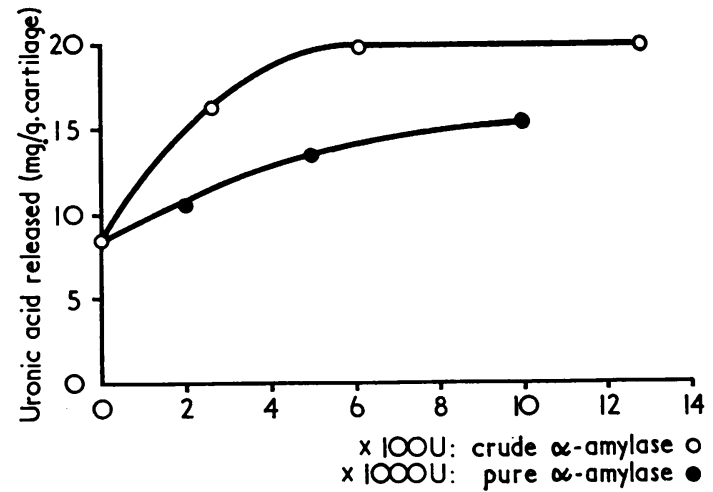

FIG. 2 Comparison of effect of different concentrations of crude a-amylase and purified a-amylase on uronic acid release from dried costal cartilage powder from a 42-yearold cadarer.

analyses of the supernatant after incubation of the cartilage samples in phosphate buffer with or without crude $a$-amylase, the enzyme released some protein. The amount of amino acids liberated during incubation with the enzyme is three to seven times greater than during incubation with phosphate buffer only.

The results (Table III, overleaf) suggest that there is an inverse relationship between age and the amount of amino acids released by crude $a$-amylase, the total amount of amino acids dissolved from juvenile cartilage being about 1.5 times greater than that from senescent cartilage.

Hydroxyproline and hydroxylysine were found in the hydrolysates after incubation with phosphate buffer from three out of four cartilage samples (Table IV, overleaf). In comparison with the control experiments (buffer only), crude $a$-amylase causes not only an increase in total protein breakdown, but also an increase in the collagen-specific amino acids in the supernatant. Estimated from the amino acids tabulated, collagen dissolution accounts for not more than about half of the protein released from 
Table II Amount of uronic acid and hexosamine (mg./g. dried cartilage) in supernatant after 1 hrs incubation in phosphate buffer and in phosphate buffer plus purified a-amylase $(25.000 \mathrm{U} / \mathrm{g}$. cartilage)

\begin{tabular}{|c|c|c|c|c|c|c|}
\hline \multirow{2}{*}{$\begin{array}{l}\text { Age } \\
(y r s)\end{array}$} & \multicolumn{3}{|c|}{ Uronic acid released } & \multicolumn{3}{|c|}{ Hexosamine released } \\
\hline & $\begin{array}{l}\text { Phosphate } \\
\text { buffer }\end{array}$ & $\begin{array}{l}\text { Phosphate buffer }+ \\
\text { a-amylase }\end{array}$ & $\begin{array}{l}\text { 'Net effect' of } \\
\text { a-amylase }\end{array}$ & $\begin{array}{l}\text { Phosphate } \\
\text { buffer }\end{array}$ & $\begin{array}{l}\text { Phosphate buffer }+ \\
\text { a-amylase }\end{array}$ & $\begin{array}{l}\text { 'Net effect' of } \\
\text { a-amylase }\end{array}$ \\
\hline $\begin{array}{l}19 \\
46 \\
84\end{array}$ & $\begin{array}{r}30 \cdot 3 \\
7 \cdot 0 \\
3 \cdot 7\end{array}$ & $\begin{array}{r}47 \cdot 5 \\
10 \cdot 2 \\
4 \cdot 9\end{array}$ & $\begin{array}{r}17 \cdot 2 \\
3 \cdot 2 \\
1 \cdot 2\end{array}$ & $\begin{array}{r}42 \cdot 5 \\
16 \cdot 4 \\
8 \cdot 8\end{array}$ & $\begin{array}{l}76 \cdot 0 \\
48 \cdot 5 \\
20 \cdot 1\end{array}$ & $\begin{array}{l}33 \cdot 5 \\
22 \cdot 1 \\
11 \cdot 3\end{array}$ \\
\hline
\end{tabular}

Table III Amount of amino acids (mmol amino acids per $g$. dried cartilage) found in hydrolysed supernatant after incubation of dried cartilage powder in phosphate buffer and phosphate buffer plus crude a-amylase (1600 U/g. cartilage). Sum of amino acids does not include tryptophane and methionine

\begin{tabular}{llll}
$\begin{array}{l}\text { Age } \\
\text { (yrs) }\end{array}$ & \multicolumn{2}{l}{ Protein released } \\
\cline { 3 - 4 } & $\begin{array}{l}\text { Phosphate } \\
\text { buffer }\end{array}$ & $\begin{array}{l}\text { Phosphate buffer } \\
\text { crude a-amylase }\end{array}$ & $\begin{array}{l}\text { 'Net effect' of } \\
\text { crude a-amylase }\end{array}$ \\
\cline { 3 - 4 } & 0.64 & 2.18 & 1.54 \\
34 & 0.64 & 1.68 & 1.39 \\
86 & 0.14 & 1.08 & 0.94 \\
93 & 0.28 & 1.21 & 0.93
\end{tabular}

the cartilage, even in the 14-year-old sample. Crude $a$-amylase seems to release relatively more tyrosine and less glycine, hydroxyproline, and hydroxylysine from adult and senescent cartilage than from young cartilage. No other conclusive age-related changes in amino acid composition of the extracts were observed. No amino acid analyses were performed on the supernatant resulting from pure $a$-amylase digestion. Because of the very high concentrations of this preparation which had to be used, the results would have been influenced by the unknown concentration of the enzyme in the supernatant.

\section{Discussion}

The results of the experiments presented demonstrate a marked decline with age in the solubility of human costal cartilage constituents in a weak acid isotonic buffer. This age-related solubility pattern is more marked for the glycosaminoglycans than for the protein fraction. Both the hexosamine and the uronic acid content of the buffer extract decrease exponentially with increasing age of the cartilage sample. As demonstrated by the hexosamine/uronic acid ratio, the hexosamine release declines slightly more with ageing than the uronic acid release. This is in spite of the fact that the relative amount of hexosamine present in the ageing costal cartilage matrix, increases when compared to uronic acid, because of the partial replacement of chondroitin sulphates by keratan sulphate during the first four decades of human life (Kaplan and Meyer, 1959; Mathews and Glagov, 1966).

Table IV Amino acid composition (residues/1000) of soluble fraction from human costal cartilage of different ages in phosphate buffer with or without crude a-amylase

\begin{tabular}{|c|c|c|c|c|c|c|c|c|c|c|c|c|}
\hline \multirow[t]{2}{*}{ Amino acid } & \multicolumn{4}{|c|}{ Phosphate buffer } & \multicolumn{4}{|c|}{ Phosphate buffer + crude a-amylase } & \multicolumn{4}{|c|}{ 'Net effect' of crude a-amylase } \\
\hline & $14 y r s$ & 37 yrs & 86 yrs & 93 yrs & 14 yrs & 37 yrs & 86 yrs & 93 yrs & $14 y r s$ & 37 yrs & 86 yrs & 93 yrs \\
\hline $\begin{array}{l}\text { Hydroxyproline } \\
\text { Aspartic acid } \\
\text { Threonine } \\
\text { Serine } \\
\text { Glutamic acid } \\
\text { Proline } \\
\text { Glycine } \\
\text { Alanine } \\
\text { Half-cystine } \\
\text { Valine } \\
\text { Isoleucine } \\
\text { Leucine } \\
\text { Tyrosine } \\
\text { Phenylalanine } \\
\text { Hydroxylysine } \\
\text { Lysine } \\
\text { Histidine } \\
\text { Arginine }\end{array}$ & $\begin{array}{r}25 \cdot 5 \\
64 \cdot 4 \\
46 \cdot 7 \\
53 \cdot 4 \\
113 \cdot 8 \\
108 \cdot 8 \\
199 \cdot 7 \\
88 \cdot 2 \\
3 \cdot 5 \\
77 \cdot 6 \\
26 \cdot 9 \\
57 \cdot 9 \\
13 \cdot 0 \\
23 \cdot 4 \\
7 \cdot 5 \\
24 \cdot 5 \\
12 \cdot 3 \\
52 \cdot 8\end{array}$ & $\begin{array}{r}22 \cdot 9 \\
69 \cdot 3 \\
46 \cdot 3 \\
64 \cdot 8 \\
112 \cdot 0 \\
95 \cdot 1 \\
176 \cdot 5 \\
84 \cdot 5 \\
3 \cdot 8 \\
95 \cdot 8 \\
29 \cdot 4 \\
58 \cdot 8 \\
19 \cdot 3 \\
23 \cdot 0 \\
4 \cdot 7 \\
26 \cdot 1 \\
13 \cdot 1 \\
54 \cdot 6\end{array}$ & $\begin{array}{r}\overline{90} \cdot 7 \\
60 \cdot 5 \\
64 \cdot 3 \\
119 \cdot 7 \\
87 \cdot 9 \\
153 \cdot 9 \\
104 \cdot 0 \\
\overline{96} \cdot 7 \\
34 \cdot 7 \\
66 \cdot 6 \\
12 \cdot 1 \\
32 \cdot 3 \\
\overline{26} \cdot 9 \\
10 \cdot 2 \\
42 \cdot 2\end{array}$ & $\begin{array}{r}35 \cdot 6 \\
83 \cdot 1 \\
57 \cdot 3 \\
54 \cdot 4 \\
116 \cdot 4 \\
85 \cdot 7 \\
170 \cdot 6 \\
88 \cdot 0 \\
\overline{75 \cdot} \cdot 2 \\
33 \cdot 7 \\
66 \cdot 7 \\
24 \cdot 3 \\
29 \cdot 7 \\
3 \cdot 1 \\
25 \cdot 3 \\
9 \cdot 8 \\
41 \cdot 4\end{array}$ & $\begin{array}{r}57 \cdot 4 \\
60 \cdot 1 \\
33 \cdot 4 \\
46 \cdot 6 \\
102 \cdot 4 \\
100 \cdot 0 \\
270 \cdot 5 \\
88 \cdot 6 \\
4 \cdot 4 \\
50 \cdot 8 \\
20 \cdot 9 \\
48 \cdot 9 \\
9 \cdot 3 \\
19 \cdot 6 \\
11 \cdot 9 \\
20 \cdot 8 \\
9 \cdot 1 \\
45 \cdot 2\end{array}$ & $\begin{array}{r}22 \cdot 8 \\
80 \cdot 2 \\
55 \cdot 4 \\
67 \cdot 5 \\
115 \cdot 4 \\
87 \cdot 9 \\
171 \cdot 1 \\
74 \cdot 1 \\
4 \cdot 8 \\
73 \cdot 7 \\
33 \cdot 8 \\
64 \cdot 9 \\
23 \cdot 3 \\
25 \cdot 0 \\
8 \cdot 5 \\
27 \cdot 8 \\
12 \cdot 5 \\
51 \cdot 1\end{array}$ & $\begin{array}{r}29 \cdot 6 \\
85 \cdot 0 \\
60 \cdot 4 \\
56 \cdot 4 \\
117 \cdot 9 \\
81 \cdot 9 \\
169 \cdot 8 \\
80 \cdot 2 \\
3 \cdot 5 \\
72 \cdot 2 \\
33 \cdot 3 \\
70 \cdot 0 \\
24 \cdot 9 \\
28 \cdot 9 \\
8 \cdot 3 \\
26 \cdot 1 \\
9 \cdot 6 \\
42 \cdot 7\end{array}$ & $\begin{array}{r}46 \cdot 0 \\
92 \cdot 5 \\
59 \cdot 2 \\
55 \cdot 2 \\
63 \cdot 9 \\
92 \cdot 1 \\
204 \cdot 1 \\
90 \cdot 3 \\
6 \cdot 6 \\
36 \cdot 6 \\
37 \cdot 6 \\
75 \cdot 1 \\
23 \cdot 8 \\
31 \cdot 0 \\
7 \cdot 3 \\
25 \cdot 2 \\
9 \cdot 0 \\
44 \cdot 4\end{array}$ & $\begin{array}{r}67 \cdot 4 \\
58 \cdot 8 \\
29 \cdot 3 \\
44 \cdot 5 \\
98 \cdot 8 \\
97 \cdot 3 \\
292 \cdot 6 \\
88 \cdot 7 \\
4 \cdot 6 \\
42 \cdot 5 \\
19 \cdot 1 \\
46 \cdot 1 \\
8 \cdot 1 \\
18 \cdot 4 \\
13 \cdot 3 \\
19 \cdot 7 \\
8 \cdot 0 \\
42 \cdot 9\end{array}$ & $\begin{array}{r}22 \cdot 8 \\
82 \cdot 5 \\
57 \cdot 4 \\
68 \cdot 1 \\
116 \cdot 2 \\
86 \cdot 4 \\
170 \cdot 0 \\
71 \cdot 9 \\
5 \cdot 0 \\
69 \cdot 1 \\
34 \cdot 7 \\
66 \cdot 1 \\
24 \cdot 1 \\
25 \cdot 4 \\
9 \cdot 3 \\
28 \cdot 1 \\
12 \cdot 3 \\
50 \cdot 4\end{array}$ & $\begin{array}{r}34 \cdot 1 \\
84 \cdot 1 \\
60 \cdot 3 \\
55 \cdot 1 \\
117 \cdot 6 \\
81 \cdot 0 \\
172 \cdot 2 \\
76 \cdot 6 \\
4 \cdot 0 \\
69 \cdot 0 \\
33 \cdot 1 \\
70 \cdot 5 \\
26 \cdot 8 \\
28 \cdot 4 \\
9 \cdot 5 \\
25 \cdot 4 \\
9 \cdot 5 \\
42 \cdot 8\end{array}$ & $\begin{array}{r}49 \cdot 2 \\
95 \cdot 4 \\
59 \cdot 8 \\
55 \cdot 4 \\
47 \cdot 9 \\
94 \cdot 0 \\
214 \cdot 3 \\
91 \cdot 0 \\
8 \cdot 6 \\
24 \cdot 9 \\
38 \cdot 8 \\
77 \cdot 7 \\
23 \cdot 6 \\
31 \cdot 4 \\
8 \cdot 6 \\
25 \cdot 2 \\
8 \cdot 8 \\
45 \cdot 3\end{array}$ \\
\hline
\end{tabular}


Not only the glycosaminoglycan composition of human costal cartilage but also its protein composition undergoes a marked change during life, when the proportion of non-collagenous protein increases almost three-fold (Miller and others, 1969). The results reported here suggest that at the same time the solubility of the protein fraction in a weak acid buffer diminishes slightly. The changing amino acid composition of ageing costal cartilage is not reflected in the composition of the buffer-soluble fraction. Three of the four cartilage extracts contained at least some hydroxyproline and hydroxylysine. In an earlier study (Miller and others, 1969), a more conspicuous decline of cartilage solubility, and especially of the collagen fraction in 5 molar guanidine $\mathrm{HCl}$, was found with increasing age.

The effect of crude $a$-amylase activity on the powdered cartilage demonstrates an age-related decrease almost parallel to the age pattern of solubilization in phosphate buffer. However, in contrast to buffer extraction, amylase activity solubilizes relatively more hexosamine than uronic acid with increasing age. The hexosamine/uronic acid ratio of the crude $a$-amylase extract increases almost eight-fold from adolescence to senescence.

Similar results were obtained, in both the qualitative and the quantitative aspects of glycosaminoglycan solubilization, by using a purified a-amylase preparation instead of crude a-amylase. However, crude $a$-amylase was found to be far more effective in dissolving glycosaminoglycans from the cartilage. This difference might be due to the presence of proteolytic components in the crude a-amylase preparation, as suggested by the significant increase of protein or protein-derived breakdown products in the supernatant, if crude $a$-amylase was added to the phosphate buffer. Although the proteolytic contamination of crude $a$-amylase might enhance the degrading action on cartilage, it does not seem to be responsible for the age pattern.

Like the action on glycosaminoglycans the quantitative effect of crude $a$-amylase on protein release from the cartilage is age dependent. However, the age pattern of protein release is less pronounced than that for glycosaminoglycan release. The amino acid composition of the soluble material obtained by crude $a$-amylase digestion confirms the presence of a collagenolytic component in crude a-amylase (Steven, 1964). Collagenolysis was most marked on young cartilage. Otherwise, the different composition of the crude $a$-amylase extract from juvenile cartilage in comparison with adult and senescent cartilage seems to reflect the change in the amino acid composition of the costal cartilage matrix with age (Miller and others, 1969).

Further experimentation will be needed to gain insight in the age-related phenomena reported here. In the meantime it should be realized that the results of studies involving enzyme digestion or solvent extraction of human costal cartilage are strongly dependent on the age of the material used.

\section{Summary}

Pulverized human costal cartilage samples from cadavers of varying ages were extracted by isotonic phosphate buffer, $\mathrm{pH} 6 \cdot 9$, and digested by crude or purified $\alpha$-amylase. In both types of experiment, the amounts of glycosaminoglycans and proteins released were strongly dependent upon the age of the cartilage used. The quantity of hexosamine and uronic acid solubilized by phosphate buffer from senescent cartilage was about 10 per cent. of the quantity extracted from juvenile cartilage. The effectiveness of $a$-amylase digestion also decreases markedly with age, but-in contrast with buffer extraction-this decrease is more marked in regard to the release of uronic acid than to that of hexosamine. Crude a-amylase was found to be far more effective in digesting costal cartilage than purified a-amylase, probably through proteolytic contamination.

The authors are indebted to the Dutch Rheumatism Association for the financial support of this investigation. They wish to thank Dr. L. Sokoloff and Dr. E. J. Miller for their advice during the preparation of this paper.

\section{References}

Antonopoulos, C. A., Gardell, S., Szirmai, J. A., And Tyssonsk, E. R. DE (1964) Biochim. biophys. Acta, 83, 1 (Determination of glycosaminoglycans (mucopolysaccharides) from tissues on the microgram scale).

BITter, T., AND MUIR, H. M. (1962) Anal. Biochem. 4, 330 (A modified uronic acid carbazole reaction).

KaPlan, D., AND MeYer, K. (1959) Nature (Lond.) 183, 1267 (Ageing of human cartilage).

Korst, J. K. VAN DeR, Sokoloff, L., AND MilleR, E. J. (1968) Arch. Path., 86, 40 (Senescent pigmentation of cartilage and degenerative joint disease).

Mathews, M. B., AND GlaGov, S. (1966) J. clin. Invest., 45, 1103 (Acid mucopolysaccharide patterns in aging human cartilage).

Miller, E. J., Korst, J. K. vAN DER, AND SOKOlOFF, L. (1969) Arthr. and Rheum., 12, 21 (Collagen of human articular and costal cartilage).

- AND PIEZ, K. A. (1966) Anal. Biochem., 16, 320 (An accelerated single column procedure for the automatic analysis of amino acids in collagen and elastin hydrolysates).

Quintarelli, G., Dellovo, M. C., Balduini, C., and Castellani, A. A. (1969) Histochemie, 18, 373 (The effects of alpha amylase on collagen-proteoglycans and collagen-glycoprotein complexes in connective tissue matrices).

Steven, F. S. (1964) Ann. rheum. Dis., 23, 300 (The Nishihara technique for the solubilization of collagen). 